\title{
A Study on Profitability Management of Restaurants in Tamilnadu
}

\author{
B Kayathiri Bai1, Dr. V Buvaneswaran ${ }^{2}$
}

\begin{abstract}
${ }^{1}$ Research Scholar, Assistant Professor in Commerce, PG Department of Commerce, S.T.E.T. Women's College, Sudarkkottai, Mannargudi, Thirvarur Dist, Tamilnadu, India

${ }^{2}$ Research Advisor, Assistant Professor in Commerce, PG and Research Department of Commerce, Rajah Serfoji Government College, (Autonomous), Thanjavur-612005, Tamilnadu, India
\end{abstract}

\begin{abstract}
The hotel industry is a mature industry marked by intense competition. Market share increases typically comes at a competitor's expense. Industry-wide, most growth occurs in the international, rather than the domestic area. Hotels are a major employment generator in Hospitality industry. Work in the area of Hotel Management involves ensuring that all operations, including accommodation, food and drink and other hotel services run smoothly. It includes instructions in hospitality administration, hotel/motel management, restaurant and food services management, facilities planning, leisure studies, recreation administration, marketing, recreation equipment and grounds operations and maintenance, business finance, insurance and taxation, event management and guest services, personnel management, travel and logistics management, safety and health services, professional standards and ethics, and applications to specific vacation types and locations.
\end{abstract}

Keywords: Profitability Analysis; Hotel Industries

\section{Introduction}

Presently there are 1593 classified hotels with a capacity of 95,087 rooms in the country. The hotels sector comprises various forms of accommodation, namely star category hotels, heritage category hotels, timeshare resorts, apartment

\section{Gross Profit Ratio}

The gross profit margin looks at cost of goods sold as a percentage of sales. This ratio looks at how well a company controls the cost of its inventory and the manufacturing of its products and subsequently pass on the costs to its customers. The larger the gross profit margin, the better for the company. Both terms of the equation comes from the company's income statement. The calculation is:

$$
\text { Gross profit ratio }=\mathrm{x} 100
$$

Table 2: Gross profit to sales Ratio in percentage

\begin{tabular}{|c|c|c|c|c|c|c|}
\hline Year $\rightarrow$ Hotels & 2012 & 2013 & 2014 & 2015 & 2016 & Average \\
\hline Taj coromandel, & 26.89 & 21.50 & 19.92 & 19.64 & 12.66 & 20.122 \\
\hline $\begin{array}{c}\text { ITC Grand Chola } \\
\text { Hotel }\end{array}$ & 46.67 & 34.58 & 26.54 & 24.74 & 4.71 & 27.45 \\
\hline Hyatt Regency, & 20.19 & 21.44 & 21.53 & 21.20 & 21.50 & 21.17 \\
\hline Hilton Chennai, & 27.58 & 21.05 & 22.96 & 16.29 & 17.04 & 20.98 \\
\hline The Leela Pala & 37.32 & 23.58 & 15.36 & 19.12 & -14.64 & 16.15 \\
\hline Average & 31.73 & 24.43 & 21.26 & 20.20 & 8.25 & 105.87 \\
\hline
\end{tabular}

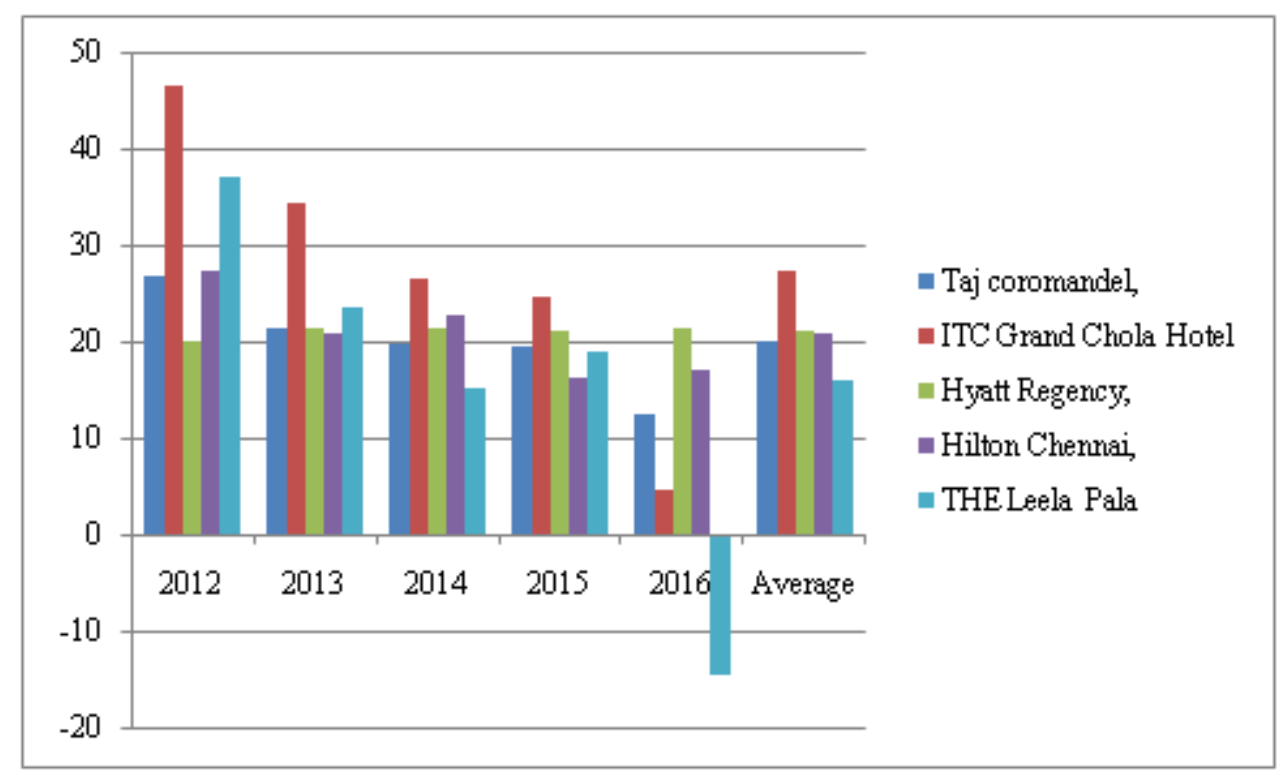

Chart 1: Gross profit to sales Ratio in percentage

Volume 5 Issue 6, June 2016 www.ijsr.net

Licensed Under Creative Commons Attribution CC BY 


\section{International Journal of Science and Research (IJSR) \\ ISSN (Online): 2319-7064}

Index Copernicus Value (2013): 6.14 | Impact Factor (2015): 6.391

Table 3: Two Way ANOVA of Selected Sample Unit of Gross Profit Ratio

\begin{tabular}{|c|c|c|c|c|c|}
\hline $\begin{array}{c}\text { Sources of } \\
\text { variance }\end{array}$ & $\begin{array}{c}\text { Degree of } \\
\text { freedom }\end{array}$ & $\begin{array}{c}\text { Sum of } \\
\text { square }\end{array}$ & $\begin{array}{c}\text { Mean sum of } \\
\text { square [MSS] }\end{array}$ & Fc & Ft \\
\hline CSS & 4 & 328.81 & 82.20 & 1.07 & $\begin{array}{r}(4,16) \\
{[3.01]}\end{array}$ \\
\hline RSS & 4 & 1368.57 & 342.14 & 4.45 & $\begin{array}{r}(4,16) \\
{[3.01]}\end{array}$ \\
\hline ESS & 16 & 1227.7 & 76.73 & & \\
\hline TSS & 24 & 2925.08 & & & \\
\hline
\end{tabular}

\subsection{Interpretation}

- ITC Grand Chola Hotel has The highest gross profit ratio is $46.67 \%$ in the year 2012

- The Leela Palace is making the Loss at $14.64 \%$ in the year of 2016

- Hyatt Regency,

- hotel is maintaining average gross profit as $20 \%$ to 21 $\%$ throughout research period

- Taj coromandel hotel is having highest profit in year 2008 and gradually decrease every year

- Two way ANOVA table Shows, The calculated value 'F' is Higher to tabular value $F$ which shows that there is significant difference in the gross profit to sales in the units undertaken for the study for the period of the study

\subsection{Net profit ratio}

Net Profit Ratio is the relation between net profit and total income. Net Profit Ratio is usually calculated for operations only. In other words, the profit is calculated does not include profit from non-trading assets. Similarly, expenses relating to non-trading assets are excluded. In calculating Net Profit Ratio, we consider net operating profit. Also taxes and preference dividends paid are not deducted from the profit. It is always better to have a higher Net Profit Ratio for a company. Normally it is expressed in terms of percentage.

Table 4: Net profits to sales Ratio in percentage

\begin{tabular}{|c|c|c|c|c|c|c|}
\hline Year/Hotels & $\mathbf{2 0 1 2}$ & $\mathbf{2 0 1 3}$ & $\mathbf{2 0 1 4}$ & $\mathbf{2 0 1 5}$ & $\mathbf{2 0 1 6}$ & Average \\
\hline Taj coromandel & 16.00 & 13.88 & 11.01 & 7.73 & .20 & 9.76 \\
\hline ITC Grand Chola Hotel & 34.06 & 20.03 & 10.48 & 10.16 & 1.26 & 15.20 \\
\hline Hyatt Regency 1 & 8.34 & 8.71 & 9.74 & 10.93 & 11.34 & 9.81 \\
\hline Hilton Chennai & 18.38 & 13.50 & 13.58 & 8.81 & 4.84 & 11.82 \\
\hline The Leela Palace & 25.65 & 25.28 & 8.87 & 7.03 & 3.17 & 14 \\
\hline Average & 20.49 & 16.28 & 10.74 & 8.93 & 4.16 & 60.59 \\
\hline
\end{tabular}

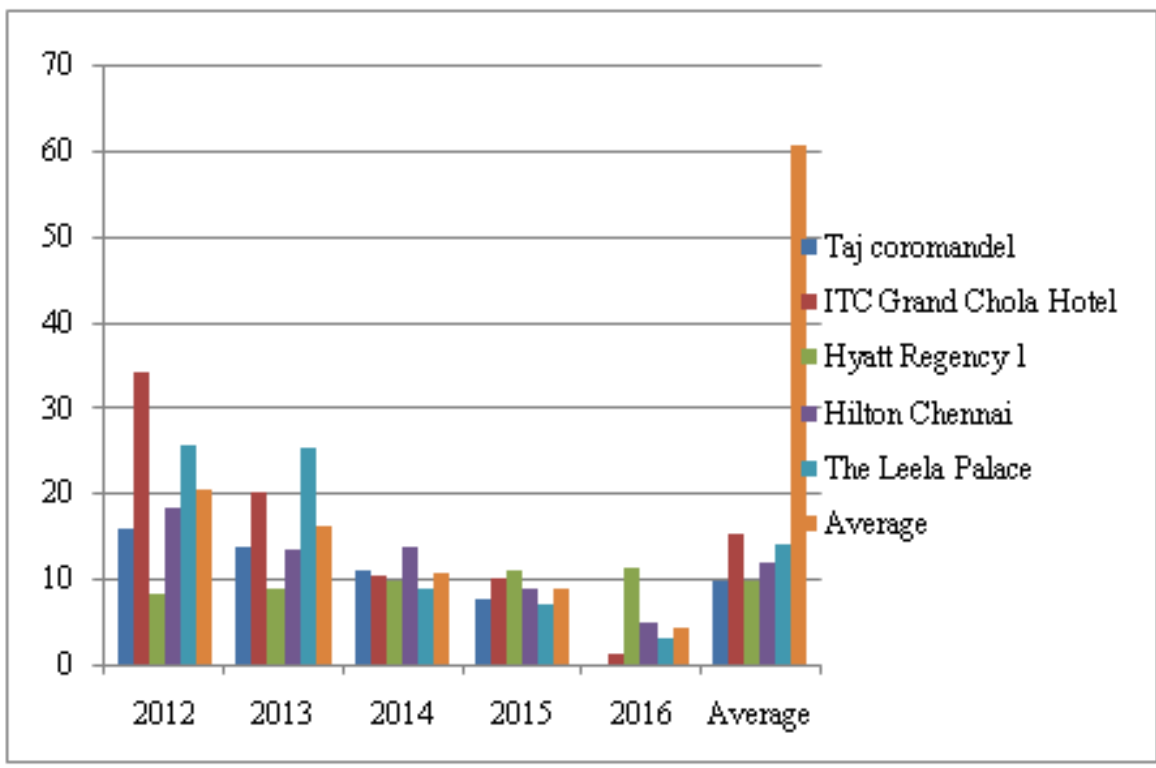

Chart 2: Net profits to sales Ratio in percentage

Table 5: Two Way ANOVA of Selected Sample Unit of Net Profit Ratio

\begin{tabular}{|c|c|c|c|c|c|}
\hline $\begin{array}{c}\text { Sources of } \\
\text { variance }\end{array}$ & $\begin{array}{c}\text { Degree of } \\
\text { freedom }\end{array}$ & $\begin{array}{c}\text { Sum of } \\
\text { square }\end{array}$ & $\begin{array}{c}\text { Mean sum of } \\
\text { Square[MSS }]\end{array}$ & Fc & Ft \\
\hline CSS & 4 & 120.33 & 30.08 & .91 & $\begin{array}{l}(4,16) \\
{[3.01]}\end{array}$ \\
\hline RSS & 4 & 813.63 & 203.40 & 6.15 & $\begin{array}{l}(4,16) \\
{[3.01]}\end{array}$ \\
\hline ESS & 16 & 529.19 & 33.07 & & \\
\hline TSS & 24 & 1463.15 & & & \\
\hline
\end{tabular}

\subsection{Interpretation}

- ITC Grand Chola Hotel is making highest Net Profit Ratio $34.06 \%$ in the year 2008 and thereafter it decreases throughout the research period
- Net Profit Ratio of the Research unit shows decrease through out research period except Hyatt Regency who is making increase in profit throughout research period

- The Leela Palace is having high profit during first two years of research period and thereafter it reduces through out the research period.

- Two way ANOVA table Shows, The calculated value 'F' is Higher to tabular value $\mathrm{F}$ which shows that there is significant difference in the net profit to sales in the units undertaken for the study for the period of the study

\subsection{Operating profit ratio}

Operating profit is also known as EBIT and is found on the company's income statement. EBIT is earnings before interest and taxes. The operating profit margin looks at EBIT

\section{Volume 5 Issue 6, June 2016 www.ijsr.net}




\section{International Journal of Science and Research (IJSR) \\ ISSN (Online): 2319-7064}

Index Copernicus Value (2013): 6.14 | Impact Factor (2015): 6.391

as a percentage of sales. The operating profit margin ratio is a measure of overall operating efficiency, incorporating all of the expenses of ordinary, daily business activity.

The calculation is:

Operating profit ratio $=\mathrm{x} 100$
Table 6: Operating profit to sales Ratio in percentage

\begin{tabular}{|c|c|c|c|c|c|c|}
\hline Year/Hotels & 2012 & 2013 & 2014 & 2015 & 2016 & Average \\
\hline Taj coromandel & 31.14 & 25.99 & 22.30 & 23.36 & 21.04 & 24.57 \\
\hline ITC Grand Chola Hotel & 50.41 & 40.62 & 33.74 & 30.78 & 10.46 & 33.20 \\
\hline Hyatt Regency & 27.83 & 28.70 & 28.75 & 27.48 & 27.50 & 28.05 \\
\hline Hilton Chennai & 35.06 & 28.29 & 31.49 & 25.16 & 26.14 & 29.23 \\
\hline The Leela Palace & 40.13 & 35.73 & 31.25 & 31.12 & 3.25 & 17.68 \\
\hline Average & 38.11 & 31.87 & 29.51 & 27.78 & 17.68 & 144.94 \\
\hline
\end{tabular}

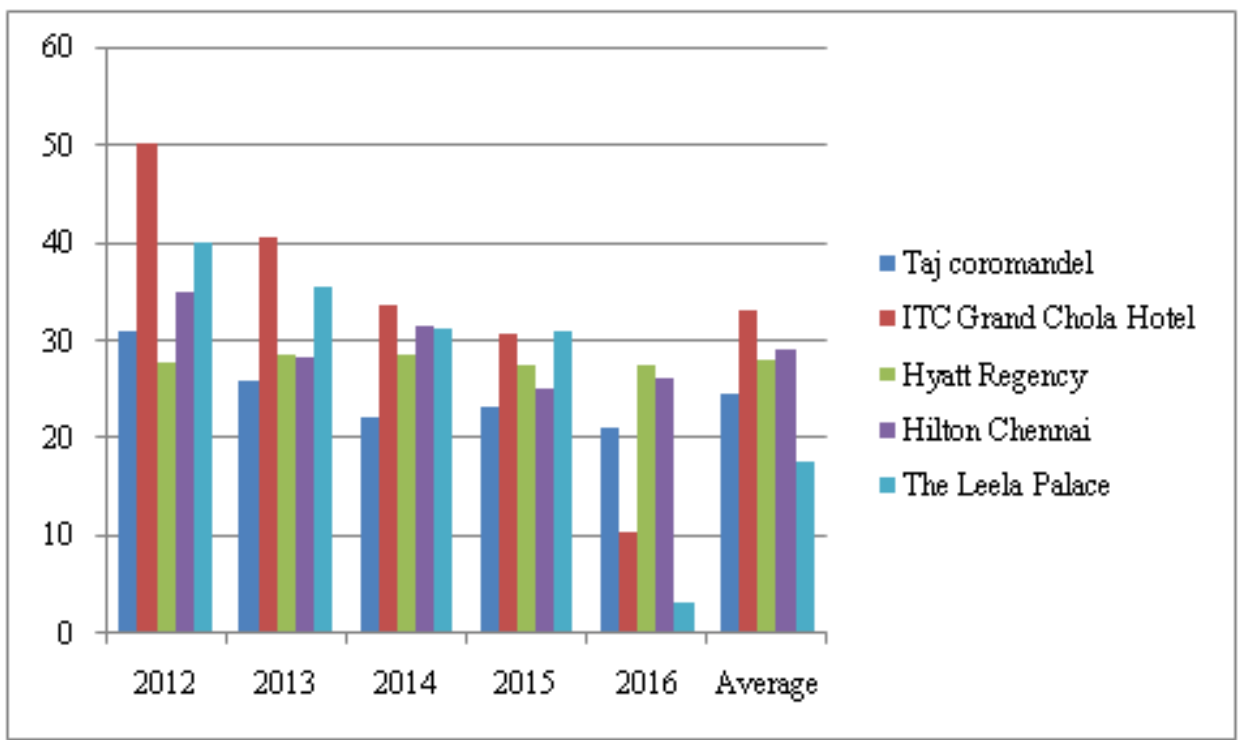

Chart 3: Operating profit to sales Ratio in percentage
Table 7: Two Way ANOVA of Selected Sample Unit of Operating Profit Ratio

\begin{tabular}{|c|c|c|c|c|c|}
\hline $\begin{array}{c}\text { Sources of } \\
\text { variance }\end{array}$ & $\begin{array}{c}\text { Degree of } \\
\text { freedom }\end{array}$ & $\begin{array}{c}\text { Sum of } \\
\text { square }\end{array}$ & $\begin{array}{c}\text { Mean sum of } \\
\text { square [MSS] }\end{array}$ & Fc & Ft \\
\hline CSS & 4 & 186.85 & 46.71 & .81 & $\begin{array}{c}(4,16) \\
{[3.01]}\end{array}$ \\
\hline RSS & 4 & 1106.03 & 276.50 & 4.84 & $\begin{array}{l}(4,16) \\
{[3.01]}\end{array}$ \\
\hline ESS & 16 & 912.71 & 57.04 & & \\
\hline TSS & 24 & 2205.59 & & & \\
\hline
\end{tabular}

\subsection{Interpretation}

- ITC Grand Chola Hotel is having highest operating profit ratio during the year 2013 @ 50.41\% and it reduces through out the research period and reaches $10.46 \%$ during the last year of research period.

- All the research unit of hotel industries shows fluctuation of operating profit ratio throughout research period except Hyatt Regency hotel who is maintaining average operating profit ratio throughout the research period.

- The Leela Palace is having high operating profit during first two years of research period and thereafter it reduces through out the research period and reaches to $3.25 \%$ in the last year of research period.

- Two way ANOVA table Shows, The calculated value 'F' is Higher to tabular value $F$ which shows that there is significant difference in the operating profit to sales in the units undertaken for the study for the period of the study

\subsection{Limitation}

- There are various kinds of hotels engaged in industry but researcher of this research has not consider all the types of hotels and period of the study is limited to 2011-12 to 2015-2016

- All the data available is from secondary source of information which has its own limitations which also apply for this research work.

- Accounting tools and Statistical techniques used for this research has their own limitation which also applies for this research work.

\section{Suggestion}

The hotel industry in India is heavily staffed. This can be gauged from the facts that while Indian hotel companies have a staff to room ratio of $3: 1$, this ratio is $1: 1$ for international hotel companies. Demand between the national and the inbound tourists can be easily managed due to difference in the period of holidays. For international tourists the peak season for arrival is between Septembers to March when the climatic conditions are suitable where as the national tourist waits for school holidays, generally the summer months.

\section{Conclusion}

Here we can say that profitability analysis of this hotel suggests that the ITC Grand Chola Hotel is in the good position than Hyatt Regency. Hilton Chennai and Taj coromandel are on an average and The Leela Palace is in the last position as compare to this five hotels.

\section{Volume 5 Issue 6, June 2016} www.ijsr.net 


\section{International Journal of Science and Research (IJSR)}

ISSN (Online): 2319-7064

Index Copernicus Value (2013): 6.14 | Impact Factor (2015): 6.391

\section{References}

[1] Shahid A. 2008. India's Best Colleges.

[2] www.livemint.com/2008/06/12000007/India8217s-

Best-Colleges.html

[3] Thadani M. HVS.Hotels in India - Trends and Opportunities,2007a.

[4] www.indialine.com. MICE Tourism in India- India,

[5] www.incredibleindia.org

[6] www.moneycontrol.com

Volume 5 Issue 6, June 2016 www.ijsr.net 